\title{
A new species of the family Sturmiidae (Collembola: Symphypleona) from Panama
}

\author{
GABRIELA CASTAÑO-MENESES ${ }^{1,2}$ \& JOSÉ G. PALACIOS-VARGAS ${ }^{1}$ \\ ${ }^{1}$ Ecología y Sistemática de Microartrópodos, Departamento de Ecología y Recursos Naturales, Facultad de Ciencias, Universidad \\ Nacional Autónoma de México.04510 México,D.F.E-mail: gcm@hp.fciencias.unam.mx; troglolaphysa@hotmail.com \\ ${ }^{2}$ Unidad Multidisciplinaria de Docencia e Investigación, Facultad de Ciencias, Campus Juriquilla, Universidad Nacional Autónoma \\ de México. Juriquilla, Querétaro, 76230,México.E-mail: gcm@hp.fciencias.unam.mx
}

\begin{abstract}
Sturmius panamaensis sp. nov. from the canopies of the San Lorenzo Forest in Panama is described and illustrated. The new species lacks a pseudonychium on the ungues, has a smaller mucro than the other species in the genus, and females have long anal appendices. A key to identify the three species known in the family is provided.
\end{abstract}

Key words: canopy debris, Sturmius panamaensis, taxonomy, key

\section{Introduction}

The genus Sturmius and the family Sturmiidae with type species, S. epiphytus from Colombia were originally described by Bretfeld (1994). The type species was found in epiphytic moss and ferns of the mountain forest remnants at 3,000-3,700 m altitude in the Páramo region. Later, Bretfeld and Gauer (1999) described Sturmius truncivivus, the only other species in the genus, from the surface of trunks of living trees in blackwater inundation forest near Manaus, Brazil, at $85 \mathrm{~m}$ altitude.

The Collembola of Panama are poorly known (Palacios-Vargas 1992). To date, only 19 species have been recorded (Castaño-Meneses \& Palacios-Vargas 2007; Palacios-Vargas 1992, 2007). Recent collections of Collembola from the forest canopies included a new species of Sturmius here described. It was found in suspended debris (sols suspendues) accumulated in canopies of San Lorenzo Forest, on the Atlantic coast of Panama at $130 \mathrm{~m}$ altitude. The collections were made by N. Winchester (University of Victoria, Canada) and K. Jordan using single rope technique and were part of the IBISCA-Panama project (http://www.naturalsciences.be/cb/ants/projects/ ibisca_main.htm). Site characteristics and collecting methods are described in detail in Basset et al. (2007).

Types are deposited at Ecología y Sistemática de Microatrópodos Collection (LESM) at Sciences Faculty, Universidad Nacional Autónoma de México, at Senckenberg Museum für Naturkunde, Görlitz, Germany (SMNG) and at the Museo de Invertebrados G.B. Fairchild, Universidad de Panamá (MIUP).

\section{Methods}

Specimens were mounted in Hoyer's solution and observed with a phase contrast light microscope. For scanning electron microscopy (SEM) they were dehydrated in gradual alcohols, dried in a Baltec CPD030 critical-point dryer, and coated with gold in Denton Vacuum Desk II sputtering device. They were photographed in a JEOL JSM 5310LV model.

The abbreviations used in the description are following: Ant.: Antennal segment; Abd.: Abdominal segment; Append. Anales $=$ Anal appendices

Nomenclature of morphology and chaetotaxy follows Bretfeld (1994). 


\section{Sturmius Bretfeld, 1994}

Type species Sturmius epiphytus Bretfeld, 1994

\section{Diagnosis modified from Bretfeld 1994}

Abdomen with $2+2$ thickened small setae dorsal to trichobothrium A; $2+2$ dorsal setae additional to normal arrangement on female abdominal segment VI; $3+3$ dorsal circum-anal setae thicker than others. Body oval to globular, variable dark blue pigment; large, protruding eye-patches, reduced abdominal segment V. Most setae fine, setae around eye-patches and some short dental setae slightly stronger. Trichobothria ABCD of normal shape, angle subtended by ABC located behind abdominal segment I, opening anteriorly. Ventral trunk setae absent, but 1 +1 neosminthuroid setae present. Abdominal segment VI ventral sensillum in row av, and female setae a0 simple, not bifurcate. Anal appendices directed towards the posterior, thick and seta-like, inserted in papilla; Ant. III with a small, simple papilla; Ant. IV with five to seven intermediate subsegments. Trochanteral organs and tibiotarsal clavate setae absent. Pretarsus with 2 setae. Ventral tube with short, smooth sacs and $1+1$ setae. Retinaculum with $3+3$ teeth and basal appendix. Furcula with few anterior setae. Mucro long, both lamellae toothed lacking setae.

\section{Sturmius panamaensis sp. nov.}

(Figs. 1-12)

Type locality. Panamá, Colón, San Lorenzo Forest.

Type material. HOLOTYPE: female, deposited at Ecología y Sistemática de Microatrópodos Collection (LESM) at Sciences Faculty, Universidad Nacional Autónoma de México. PARATYPES: 4 female paratypes, 2 preadult female paratypes, 5 male paratypes. All type material on slides. One female and one male deposited at Senckenberg Museum für Naturkunde, Görlitz, Germany; one female and one male deposited at Museo de Invertebrados G.B. Fairchild, Universidad de Panamá (MIUP); two females, two preadult females and three males deposited at Ecología y Sistemática de Microatrópodos Collection (LESM) at Sciences Faculty, Universidad Nacional Autónoma de México. All type material from: Panamá, Colón, San Lorenzo Forest ( $\left.9^{\circ} 17^{\prime} \mathrm{N}, 7^{\circ} 58^{\prime} \mathrm{W}\right)$ canopy debris in tropical rainforest at $130 \mathrm{~m}$ asl, 8-X-2003. N. Winchester \& K. Jordan leg. Additional material, more than 300 specimens are kept in alcohol at Ecología y Sistemática de Microatrópodos Collection (LESM) at Sciences Faculty, Universidad Nacional Autónoma de México.

The following description of Sturmius panamaensis sp. nov. applies to both sexes if not otherwise stated.

Measurements. Total female length up to $0.60 \mathrm{~mm}(\mathrm{~N}=7)$, male length $0.45 \mathrm{~mm}(\mathrm{~N}=5)$, juvenile $0.39 \mathrm{~mm}$ $(\mathrm{N}=10)$; female head diameter $0.21 \mathrm{~mm}(0.18-0.21)$, male $0.16 \mathrm{~mm}(0.15-0.16)$, juvenile $0.15 \mathrm{~mm}(0.11-0.25)$; female mucro $66 \mu \mathrm{m}$ (50-82), male $57 \mu \mathrm{m}$ (50-58), juvenile $41 \mu \mathrm{m}$ (27.5-42); female appendices anales $82 \mu \mathrm{m}$ (62.5-100).
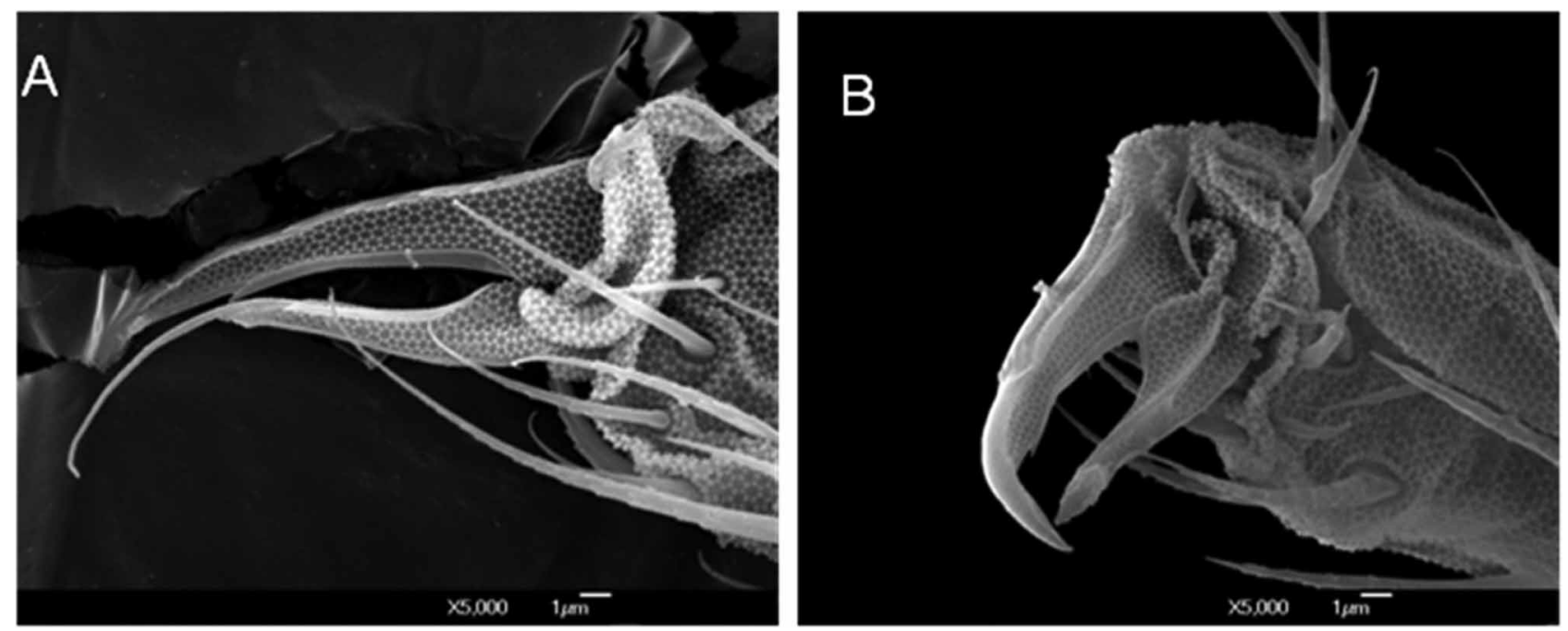

FIGURE 1. Sturmius panamaensis sp. nov. SEM photographs. A, apex of tibiotarsus I. B, apex of tibiotarsus II. 

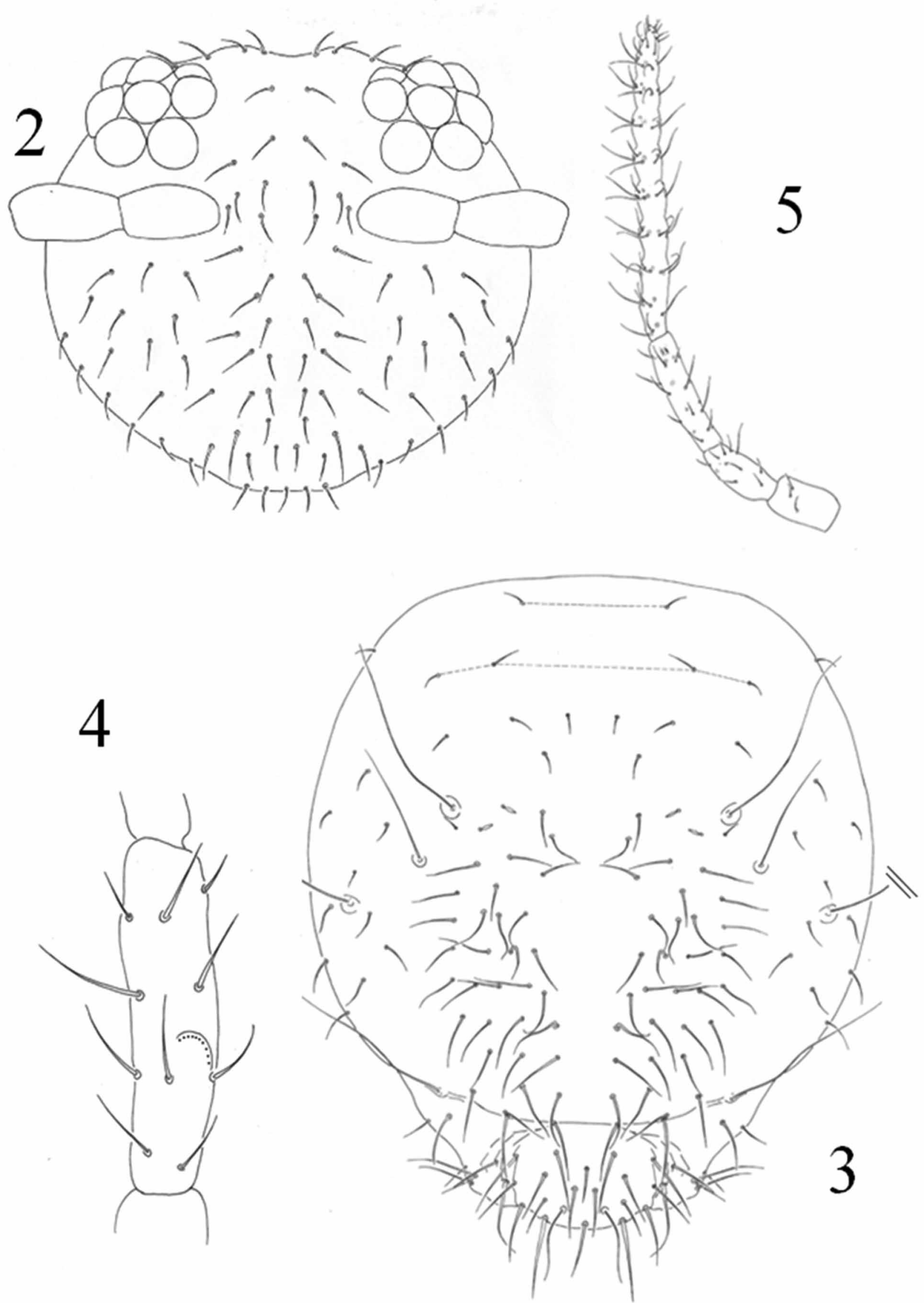

FIGURES 2-5. Sturmius panamaensis sp. nov. female, 2, head chaetotaxy. 3, body dorsal chaetotaxy. 4, Ant. III, dorsal view. 5 , complete antenna. 


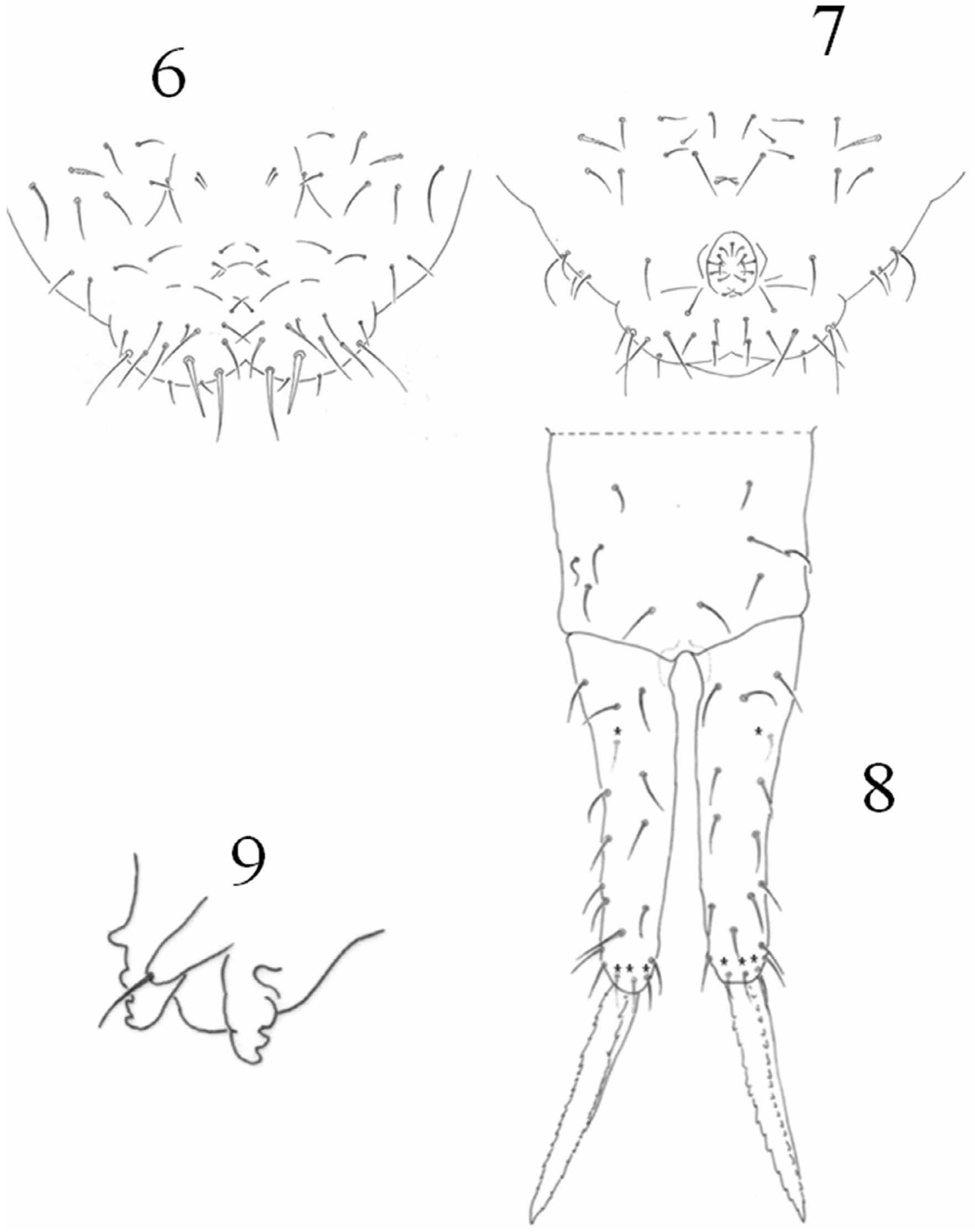

FIGURES 6-9. Sturmius panamaensis sp. nov. 6, female abdominal segments V and VI in ventral view. 7, male abdominal segments V and VI in ventral view, and genital plate. 8, female furcula from posterior side, *ventral seta. 9, female retinaculum.

Proportions. Whole antenna: head length ratio $=1.73(1.58-1.90)$ in females, $1.53(1.59-1.90)$ in males, and 1.48 in juveniles (1.17-1.67). Ant. I: II; III; IV ratio = 1: $1.68(1.0-2.5)$; 2.75 (1.75-4.5); 6.85 (4.38-11.0) in females, 1: 1.31 (1.0-1.8); 2.09 (1.71-3.0); 4.94 (3.28-7.0) in males, and 1: 1.39 (1.0-1.75); 2.06 (1.5-2.75); 4.87 (1.96-6.75) in juveniles. Ant. IV distal part: proximal part ratio $=2.6(2.3-3.4)$. Mucro: dens; manubrium ratio $=1$ : 1.52 (1.25-1.8); 1.37 (1.2-1.6) in females, 1: 1.48 (1.28-1.77); 1.27 (0.91-1.51) in males, and 1: 1.49 (0.81-1.8); $1.42(0.75-1.8)$ in juveniles. Appendices anales: unguis III inner edge ratio $=2.7$ (2.5-3.09). Mucro: unguis III inner edge ratio $=2.5(1.78-3.25)$ in females; $2.64(2.25-3.05)$ in males, and $2.51(1.56-3.75)$ in juveniles. Mucro: appendices anales ratio $=0.89(0.71-1.07)$. 
Pigmentation. Eye-patches deep black. General colour of the females and males dark blue-purple. Cuticle forming hexagonal patterns of primary granules and secondary granules with triangular tip, similar to Actaletes or Sphaeridia (Bretfeld, 1994).

Head. Eye-patches protruding with $8+8$ ommatidia (Fig. 2). Smallest ommatidium is E. Ant. I with 7 setae, Ant. II with 12 setae, and Ant. III with 17 setae and a simple papilla (Fig. 4); Ant. III sensory organ with two sensilla concealed in one cavity, separated by a short cuticular fold. Ant. IV with 8 whorls of setae but poorly defined subsegments (Fig. 5).

Legs. Precoxa 1on leg I lacking seta. Legs II and III with one seta on precoxa 1; precoxa 2 on legs I-III with 1 seta each. Coxa I-III with 4 setae; trochanter I-III with 4 setae each, femur I, II, III with proximal/medial/distal setae as 2/3/7, 3/3/7, 3/3/6 respectively. Tibiotarsi (Figs. 10,11,12) with distal whorls and longitudinal rows of setae. Ungues without pseudonychium. Ungues I-III with small inner tooth; ungues II with thickened setae distally. Only empodial appendage I with a long filament exceeding claw (Figs. 1A, 10a); empodial appendage II strong, with thick tip but without filament (Figs. 1B, 11a), empodial appendage III slender without filament (Fig. 12b). Tibiotarsi with some setae p slightly barbulate as S. truncivivus; oval organs small, obscure.

Abdomen. Form as for genus (Fig. 3). Trichobotrium B shortest. Row 1, $1+1$ seta; row 2, $3+3$ setae (rows are indicated with dashed lines in Fig. 3). Most setae fine and straight, $2+2$ flame-shaped fairly short spines dorsal to trichobothrium A on each side. Ventral trunk setae absent. Furcula base with $10+10$ setae, seta 3 being a relatively long and thin neosminthuroid seta (Fig. 6). Small abdomen with Abd. V short, protruding into the great abdomen. Abdomen VI as in Figure 6. Trichobothrium D similar to A. Setae $\mathrm{sa}_{2}$ and $\mathrm{sa}_{3}$ similar to the type species. Anal appendices (a5) similar to the type species. Males with 15 setae on the genital plate (Fig. 7).

Ventral tube. As characteristic for the genus with $1+1$ anterior distal setae. Retinaculum with one seta on corpus, each rami with one basal appendix and $3+3$ apical teeth, posterior lobe small (Fig. 9). Manubrium (Fig. 8) with $5+5$ setae, seta 1 longer than others. Dens with 8 setae in distal whorl, row J: 1 distal seta, row PE no seta, formula of anterior setae $3 \ldots 1$ from distal to basal. Ventral setae on Fig. 8 marked with *. Mucrones relatively long, thin, with both edges serrated (Fig. 8).

Derivatio nominis. From Panama, the country locality of the new species.

Discussion. Sturmius panamaensis sp. nov. is similar to the two other known species of Sturmius, but it has a shorter mucro, the spines dorsal to trichobothrium A are not so short as in the other species and are flame shaped, trichobothrium B in the new species is smaller than A and C. Also only empodial appendix I has a long filament (similar to the other two species), but the ungues II and III lack filaments, which are present in the two other species of the genus. The anal appendices of the female are longer than in other species, which affects the ratio ungues/ mucro as it is the smallest (see Table 1). Setae ai and i of tibiotarsus III of the new species are barbed, and not smooth as in the type species. The anal appendices (a5) are more similar in shape to the type species S. epiphytus. In the new species the neosminthuroid seta is long and thin, while in S. epiphytus it is short and thick. S. panamaensis sp. nov. lacks a pseudonychium on all the ungues, unlike the type species and S. truncivivus.

TABLE 1. Comparative measurements of Sturmius spp. Ant = Antennal segment; Append. Anales = Appendices anales.

\begin{tabular}{|c|c|c|c|c|c|c|c|c|c|c|c|}
\hline \multirow[t]{3}{*}{ Species } & \multicolumn{6}{|c|}{ Length } & \multirow{3}{*}{$\begin{array}{l}\text { Append. } \\
\text { anales }\end{array}$} & \multirow{2}{*}{\multicolumn{2}{|c|}{ Ant: Head }} & \multirow{2}{*}{\multicolumn{2}{|c|}{$\begin{array}{l}\text { Ratio } \\
\text { Ant: I:II;III;IV }\end{array}$}} \\
\hline & \multicolumn{2}{|c|}{ Total (mm) } & \multicolumn{2}{|c|}{ Head (mm) } & \multicolumn{2}{|c|}{$\operatorname{Mucro}(\mu \mathrm{m})$} & & & & & \\
\hline & $\mathrm{f}$ & $\mathrm{m}$ & $\mathrm{f}$ & $\mathrm{m}$ & $\mathrm{f}$ & $\mathrm{m}$ & & $\mathrm{f}$ & $\mathrm{m}$ & $\mathrm{f}$ & $\mathrm{m}$ \\
\hline S. epiphytus & 0.7 & 0.45 & 0.26 & 0.20 & 80 & 70 & 40 & 1.8 & 1.9 & $1: 1.6 ; 2.7 ; 6.7$ & $1: 1.6 ; 2.7 ; 7$ \\
\hline S. truncivivus & 0.5 & 0.35 & 0.23 & 0.16 & 75 & - & 37 & 1.8 & 1.9 & $1: 1.8 ; 3.2 ; 7.7$ & $1: 1.6 ; 2.6 ; 6$ \\
\hline \multirow[t]{4}{*}{ S. panamaensis } & 0.6 & 0.45 & 0.21 & 0.16 & 66 & 57 & 82 & 1.7 & 1.5 & $1: 1.6 ; 2.7 ; 6.5$ & $1: 1.3 ; 2.9 ; 4.9$ \\
\hline & \multicolumn{11}{|c|}{ Ratios } \\
\hline & \multicolumn{4}{|c|}{ Manubrium: Dens: mucro } & \multicolumn{3}{|c|}{ Anal spines: Ungues III } & \multicolumn{2}{|c|}{$\begin{array}{l}\text { Mucro: } \\
\text { Ungues III }\end{array}$} & \multicolumn{2}{|c|}{ Append. Anales: Mucro } \\
\hline & \multicolumn{2}{|l|}{$\mathrm{f}$} & \multicolumn{2}{|l|}{$\mathrm{m}$} & \multicolumn{3}{|l|}{$\mathrm{f}$} & \multicolumn{2}{|l|}{$\mathrm{f}$} & \multicolumn{2}{|l|}{$\mathrm{f}$} \\
\hline S. epiphytus & \multicolumn{2}{|c|}{$1: 1.4 ; 1.5$} & \multicolumn{2}{|c|}{$1: 1.5 ; 1.5$} & \multicolumn{3}{|l|}{1.4} & \multicolumn{2}{|l|}{2.8} & \multicolumn{2}{|l|}{0.5} \\
\hline S. truncivivus & \multicolumn{2}{|c|}{$1: 1.6 ; 1.6$} & \multicolumn{2}{|c|}{$1: 1.7 ; 1.7$} & \multicolumn{3}{|l|}{1.6} & \multicolumn{2}{|l|}{3.3} & \multicolumn{2}{|l|}{0.5} \\
\hline S. panamaensis & \multicolumn{2}{|c|}{$1: 1.5 ; 1.3$} & \multicolumn{2}{|c|}{$1: 1.4 ; 1.2$} & \multicolumn{3}{|l|}{2.7} & \multicolumn{2}{|l|}{2.5} & \multicolumn{2}{|l|}{0.9} \\
\hline
\end{tabular}



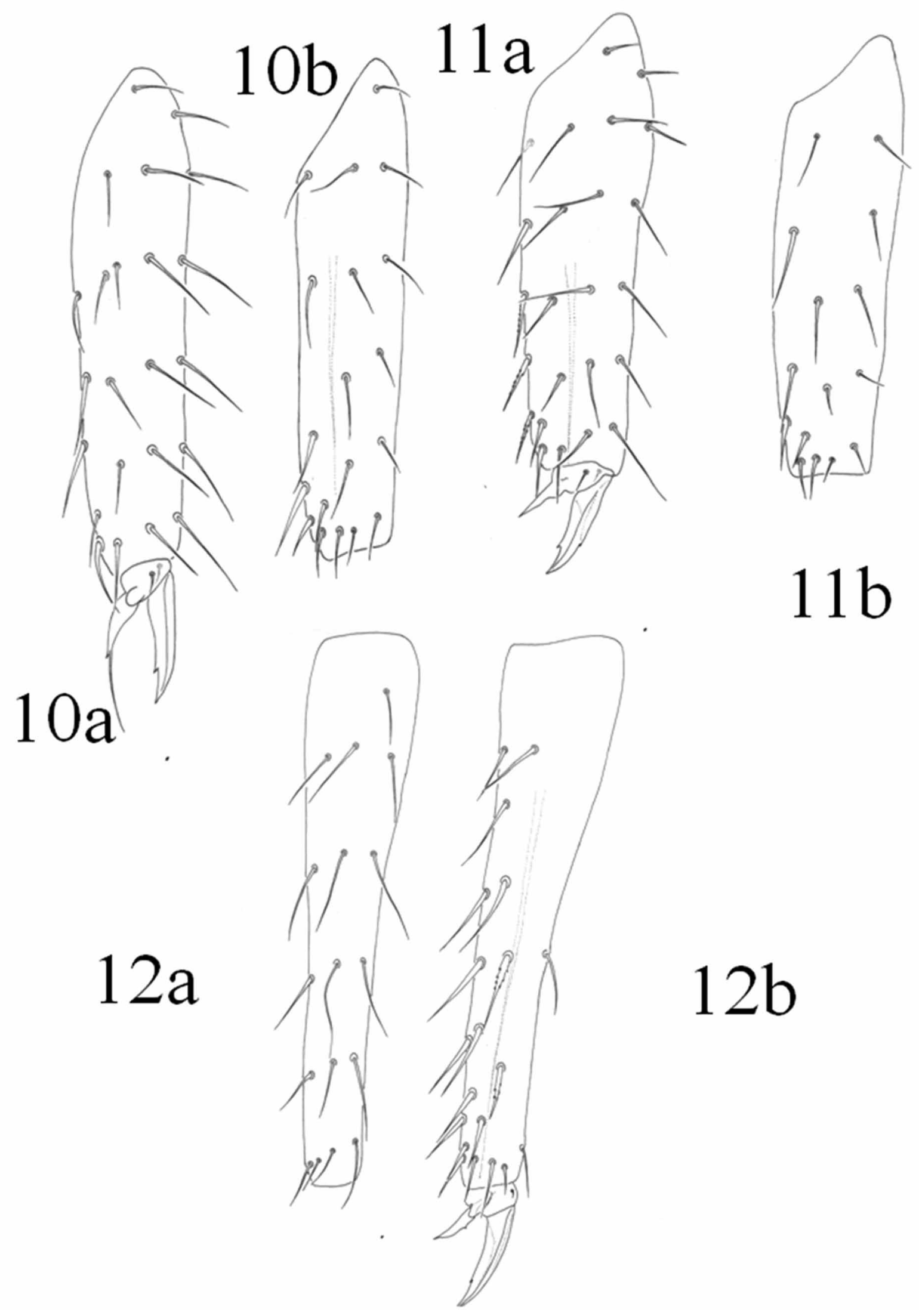

FIGURES 10-12. Sturmius panamaensis sp. nov. tibiotarsi from a female. 10a, leg I anterior view. 10b, leg I posterior view. 11a, leg II anterior view. 11b, leg II posterior view. 12a, leg III posterior view. 12b, leg III anterior view. 
Ecological notes. The new species was collected during September and October (rainy season) of 2003, in the canopy of several species of trees: Brosimum utile (Kunth) Oken, Luehea seemannii Planch. \& Triana, Vochysia ferruginea Mart., Ficus tonduzii Standl., Calophyllum longifolium Willd., Anacardium excelsum Skeels, Pourouma bicolor Mart., Trichilia tuberculata C. D.C. and Terminalia amazonia (Gmel.) Exell. A total of 405 specimens were collected, all of them were found by extracting suspended debris from the canopy in Berlese funnels at eight sites in the San Lorenzo forest in the Atlantic coast of Panama. The height of the sampling sites were 10 to $29 \mathrm{~m}$ from the base of the trees. The average $( \pm \mathrm{SD})$ of fresh weight of the samples was $59.96 \pm 23.5 \mathrm{gm}(\mathrm{N}=8)$, and the dry weight average was $20.76 \pm 7.75 \mathrm{gm}$. The mean humidity content in the samples was $65 \%$. The canopy was, on average, $6.88 \%$ open.

The genus Sturmius was previously only known from South America (Colombia and Brazil), and this is the first record for Central America. Canopy sampling in Mexico (Chiapas, Hidalgo and Jalisco States), has not collected this genus (Palacios-Vargas \& Castaño-Meneses 2003). Forest canopies in Costa Rica, El Salvador and Nicaragua need to be sampled in order to establish the northern limits for the genus.

Although there are important faunal differences in springtails assemblages, according to vegetation type, the species richness of canopy Collembola is low compared with that of soil and litter of the same area (Palacios-Vargas \& Castaño-Meneses 2003; Palacios-Vargas \& Gómez-Anaya 1993). Nevertheless some species can be abundant and make this group of canopy arthropods among the most abundant. The relevant families are Paronellidae, Entomobyridae and Bourletiellidae (Greenslade \& Sutrisno 1994; Guilbert 1997; Guilbert et al. 1995; PalaciosVargas \& González 1995; Palacios-Vargas et al. 1998; Rodgers \& Kitching 2011). All the members of the family Sturmiidae are have been found only in epiphytic environments. Some genera such as Deuterosminthurus, Willowsia, Salina and even Americanura, have representatives in soil, litter and the canopy, but not Sturmius, which has never been found in soil or litter.

\section{Acknowledgments}

The IBISCA-Panama project established by Pro-Natura International, Océan Vert, l'Université Blaise Pascal, la Universidad de Panamá and the Smithsonian Tropical Research Institute (STRI), with core funding from SolvinSolvay SA, STRI, the United Nations Environment Program, the Smithsonian Institution (Walcott fund), the European Science Foundation and the Global Canopy Program. We thank the collectors of the new species, N. Winchester \& K. Jordan (University of Victoria, Canada), and Yves Basset organizer of IBISCA-Panama project, for the opportunity to participate in the project. Dr. G. Bretfeld (Germany) reviewed the manuscript and gave critical advice. The SEM microphotographs were obtained by Dr. Silvia Espinosa-Matías (Microscopía de Barrido, Sciences Faculty, Universidad Nacional Autónoma de México). Biol. Elihú Catalán (CONACyT scholarship) made the drawings of the new species.

\section{Key to the species of Sturmius}

1. Ungues III broad, with distinct inner tooth and toothed pseudonychia, empodial appendage III not extending beyond ungues,

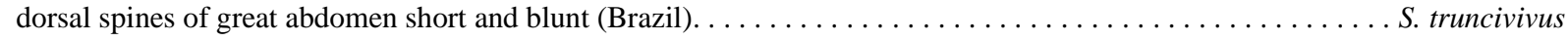
Ungues III slender, small inner tooth, empodium III extending beyond ungues $\ldots \ldots \ldots \ldots \ldots \ldots \ldots \ldots \ldots \ldots \ldots$

2. Ungues with toothed pseudonychia, dorsal spines of great abdomen slender and short, not flame shaped, anal appendices as

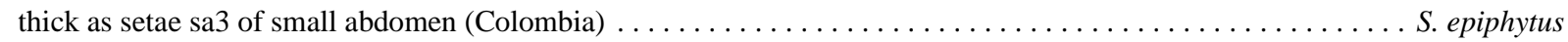
Ungues lacking pseudonychia, dorsal spines of great abdomen flame-shaped, appendices anales thicker than setae sa3 of small

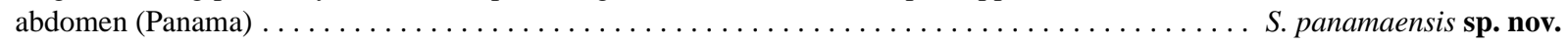

\section{References}

Basset, Y., Corbara, B., Barrios, H., Cuénoud, P., Leponce, M., Aberlenc, H.-P., Bail, J., Bito, D., Bridle, J.R., Castaño-Meneses, G., Cizek, L., Cornejo, A., Curletti, G., Delabie, J.H.C., Dejean, A., Didham, R.K., Dufrêne, M., Fagan, L.L., Floren, A., Frame, D.M., Hallé, F., Hardy, O.J., Hernandez, A., Kitching, R.L., Lewinsohn, T.M., Lewis, O.T., Manumbor, M., Medianero, E., Missa, O., Mitchell, A.W., Mogia, M., Novotny, V., Oliveira, E.G. de, Ødegaard, F., Orivel, J., Ozanne, 
C.M.P., Pascal, O., Pinzón, S., Rapp, M., Ribeiro, S.P., Roisin, Y., Roslin, T., Roubik, D.W., Samaniego, M., Schmidl, J., Sørensen, L.L., Tishechkin, A., Van Osselaer, C. \& Winchester, N.N. (2007) IBISCA-Panama, a large-scale study of arthropod beta-diversity and vertical stratification in a lowland rainforest: rationale, description of study sites and field methodology. Bulletin de l'Institut Royal des Sciences Naturelles de Belgique (Entomologie), 77, 39-69.

Bretfeld, G. (1994) Sturmius epiphytus n. gen. n. spec. from Colombia, a taxon of the Symphypleona (Insecta, Colembola) with an unexpected character combination. Description and position in non-Linnean and Linnean classifications of the Symphypleona. Journal of Zoological Systematics and Evolutionary Research, 32, 264-281.

Bretfeld, G. \& Gauer, U. (1999) A second species of the genus Sturmius Bretfeld, 1994: Sturmius truncivivus n. sp. from Brazil (Insecta, Collembola, Symphypleona). Amazoniana, 15, 279-284.

Castaño-Meneses, G. \& Palacios-Vargas, J.G. (2007) Colémbolos (Hexapoda: Collembola) del Parque Internacional La Amistad (PILA), provincia de Chiriquí, República de Panamá. Entomología mexicana, 6, 1167-1170.

Greenslade, P. \& Sutrisno (1994) Epimetrura rostrata sp. n., E. mirabilis Schött, and the status of the genus Epimetrura (Collembola: Entomobryidae). Acta Zoologica Fennica, 195, 52-57.

Guilbert, E. (1997) Arthropod diversity in the canopy of New Caledonian forest. In: Stork, N.J., Adis, J. \& Didham, R.K. (Eds.), Canopy Arthropods. Chapman \& Hall, London. pp. 265-277.

Guilbert, E., Baylac, E. \& Najt, J. (1995) Canopy arthropod diversity in a New Caledonian primary forest sampled by fogging. Pan-Pacific Entomologist, 71, 3-12.

Palacios-Vargas J.G. (1992) Guide to the Springtails of Panama and Costa Rica (Collembola). In: Quintero, D. \& Aiello, A. (Eds), Insects of Panama and Mesoamerica. Selected Studies. Oxford University Press. pp. 25-36.

Palacios-Vargas, J.G. (2007) A new species of Denisiella (Collembola: Sminthurididae) from Panama and new records for $D$. sexpinnata (Denis, 1938). Zootaxa, 1637, 63-68.

Palacios-Vargas, J.G. \& Castaño-Meneses, G. (2003) Seasonality and community composition of springtails in Mexican forests. In: Basset, Y., Novotny, V., Miller, S. E. \& Kitching, R. L. (Eds), Arthropods of Tropical Forests. Cambridge University Press, Cambridge, UK. pp. 159-169.

Palacios-Vargas, J.G. \& Gómez-Anaya, J.A. (1993) Los Collembola (Hexapoda: Apterygota) de Chamela, Jalisco, México. Distribución ecológica y claves. Folia Entomológica Mexicana, 89, 1-34.

Palacios-Vargas, J.G. \& González, V. (1995) Two new species of Deuterosminthurus (Bourletiellidae) epiphytic Collembola from the Neotropical region with a key for the American species. Florida Entomologist, 78, 286-294.

Palacios-Vargas, J.G., Castaño-Meneses, G. \& Gómez-Anaya, J.A. (1998) Collembola from the canopy of a Mexican tropical deciduous forest. Pan-Pacific Entomologist, 74, 47-54.

Rodgers, D. \& Kitching, R.L. (2011) Rainforest Collembola (Hexapoda: Collembola) and the insularity of epiphyte microhabitats. Insect Conservation and Diversity, 4, 99-106. 